\title{
Polymorphism in cardiovascular diseases (CVD) susceptibility loci in the azores islands (Portugal)
}

\author{
Mafalda Raposo ${ }^{1 *}$, Paul Sousa ${ }^{2,3^{*}}$, Stefan Nemeth $^{4}$, Ana Rita Couto ${ }^{2,3}$, Margarida Rodrigues Santos ${ }^{2}$, \\ João Paulo Pinheiro ${ }^{2}$, Maria João Peixoto ${ }^{3}$, Christian Oberkanins ${ }^{4}$, Nadiya Kazachkova ${ }^{1,3}$, \\ Teresa Cymbron ${ }^{1,3}$, Manuela Lima ${ }^{1,3}$, Jácome Bruges-Armas ${ }^{2,3}$
}

\footnotetext{
${ }^{1}$ Center of Research in Natural Resources (CIRN) and Department of Biology, University of the Azores, Ponta Delgada, Portugal;

${ }^{2}$ Specialized Service of Epidemiology and Molecular Biology (SEEBMO), Hospital of Santo Espírito, Angra do Heroísmo, Portugal;

${ }^{3}$ Institute for Molecular and Cell Biology (IBMC), University of Porto, Porto, Portugal;

${ }^{4}$ ViennaLab Diagnostics GmbH, Vienna, Austria.

Email: ${ }^{*}$ jacome@seebmo.org
}

Received 26 September 2011; revised 17 November 2011; accepted 25 November 2011

\section{ABSTRACT}

Background: Atherosclerosis and thrombosis are the major manifestations underlying cardiovascular diseases (CVD), which are the leading cause of mortality and morbidity worldwide. Both result from an interaction between genetic and environmental risk factors. The goal of our study was to evaluate several polymorphisms identified as predisposing factors to atherosclerosis and thrombosis. Material and Methods: A series of $\mathbf{1 5 5}$ healthy unrelated individuals of Azorean origin were analyzed using the CVD StripAssay (ViennaLab Diagnostics, Austria) for the most established polymorphisms involved in blood coagulation (F2, F5, F13A1, FGB), fibrinolitic system (SERPINE1), platelet adhesion (ITGB3), homocysteine metabolism (MTHFR), reninangiotensin system (ACE) and lipid metabolism (APOE). Results: No significant differences were observed in allelic frequencies when comparing our data to mainland Portugal. Group stratification according to the number of "increased" risk alleles, demonstrated that $116 / 155(75 \%)$ individuals belong to the moderate risk group (5 - 10 risk alleles). Conclusions: Although acknowledging the fact that the allelic states at the analysed loci lack predictive value, the fact that a high frequency of individuals presents at least 5 risk alleles $(124 / 155 ; 80 \%)$ is important for the establishment of the appropriate preventive measures in the Azorean population.

Keywords: Atherosclerosis; Thrombosis; Cardiovascular Diseases; Susceptibility Genes; Genetic Risk; Polymorphism

\section{INTRODUCTION}

Cardiovascular diseases (CVD) are the leading cause of morbidity and mortality worldwide [1]. It comprises several complex disorders, in which dysfunction of the heart and blood vessels is established, and where genetic and environmental factors interplay. CVD are generalized disorders of the vascular tree, characterized by longterm atheroma plaque formation which culminates in atherothrombotic obstructive lesions leading to tissue damage. Atherosclerosis and thrombosis are the two manifestations underlying CVD. It is known that events such as endothelial dysfunction, inflammation, abnormal lipoprotein and homocysteine metabolism, as well as dysfunctional coagulation and fibrinolysis play a key role in the pathogenesis of CVD [2]. Genetic variations affecting the production, activity, bioavailability or metabolism of factors involved in these pathways can compromise physiologic balance in favour of atherosclerosis and thrombosis pathogenesis [3]. Polymorphic variations in several CVD susceptibility loci have been identified and extensively investigated worldwide. Their characterization increases the knowledge of the epidemiological representation of this important cluster of disorders and provides an important basis for its management.

Ischemic Heart Disease (IHD) is one of the phenoltypes associated with atherosclerosis; IHD presents a $\sim 2$ fold higher prevalence in the Azores islands (113.3/ 100,000 inhabitants), as compared to mainland Portugal (72.5/100,000 inhabitants) [4]. The impact of the genetic factors in the prevalence of IHD in the Azorean population is currently unknown. Aiming to elucidate the genetic profile of the Azorean population with respect to CVD susceptibility loci, the following mutations and polymorphism in healthy subjects from Terceira Island 
were analysed: $F 5$ c. $1691 \mathrm{G}>\mathrm{A}, F 5$ c. $4070 \mathrm{~A}>\mathrm{G}, F 2$ c. $20210 \mathrm{G}>\mathrm{A}, F 13 A 1$ c. $143 \mathrm{G}>\mathrm{T}, F G B$ c. $-455 \mathrm{G}>\mathrm{A}$, SERPINE1 c.675 - 675delinsG, ITGB3 c.176T $>\mathrm{C}$, MTHFR c.677C > T, MTHFR c.1298A > C, ACE g.11417 11704 del287, APOE c.388T $>$ C, APOE c.526C $>$ T. The majority of risk variants for each of these polymorphisms are recognized genetic risk factors for several atherosclerotic phenotypes such as IHD, venous thrombosis (VT) and stroke [3,5-9].

Evaluation of the risk allele profile, in the Azorean population, and its comparison with other populations, namely in mainland Portugal, can enhance our understanding of the underlying the high prevalence of CVD (namely IHD) in the Azores. Furthermore, this study aims to contribute with data which could be used for defining regional preventive measures for the mitigation of CVD.

\section{MATERIAL AND METHODS}

Blood samples were obtained, after informed consent, from 155 apparently healthy unrelated individuals, 74 males and 81 females, aged between 30 to 91 years, having Azorean ancestry and living in Terceira Island (Azores, Portugal). Twelve SNPs in 9 CVD susceptibility genes were analysed using the CVD StripAssay, by the ViennaLab Diagnostics. The assay covered the following loci: $F 5$ c. $1691 \mathrm{G}>\mathrm{A}$ and c.4070A $>\mathrm{G}, F 2$ c. $20210 \mathrm{G}>\mathrm{A}, F 13 A 1$ c. $143 \mathrm{G}>\mathrm{T}, F G B$ c. $455 \mathrm{G}>\mathrm{A}$, SERPINE1 c.675 - 675delinsG, ITGB3 c.176T > C, MTHFR c.677C > T, MTHFR c.1298A > C, ACE g.11417_11704 del287, APOE c.388T > C, APOE c. $526 \mathrm{C}>\mathrm{T}$.

Allele and genotype frequencies were estimated for each locus. Conformity with Hardy-Weinberg equilibrium expectations (HW) was assessed using an exact test. Allelic frequencies observed in our population were compared with those reported for mainland Portugal [10-16] and several European and non-European populations [17-29], using an exact test of population differenttiation. For the polymorphic positions in F5 and MTHFR loci, gametic phase was estimated using a Bayesian test, by applying an ELB algorithm. Linkage disequilibrium (LD) was calculated using an exact test. The measure of LD used was the $\mathrm{D} / \mathrm{D}_{\max }\left(\left|\mathrm{D}^{\prime}\right|\right)$ [30]. Haplotype frequentcies were performed by gene counting. The observed and expected frequencies obtained for MTHFR haplotypes were compared with data available for other populations [31].

Individual risk profiles for the analysed CVD loci were determined in our sample by calculating, for each subject, the ratio between the number of risk alleles (defined as the allelic variant reported in the literature to increase the CVD risk) over the total number of alleles. Stratification by number of risk alleles was performed and each individual was then assigned to one of the following groups: Group 1 defined by $\leq 5$ risk alleles (low risk); Group 2 defined by 5 to 10 risk alleles (moderate risk); and Group 3 defined by $\geq 10$ risk alleles (high risk).

Statistical packages used were Arlequin, Genepop and SPSS software v.15.0 [32-34]. The criterion for statisticcal significance was $p<0.05$.

\section{RESULTS}

Allele and genotype frequencies for the loci analysed in this study are shown in Table $\mathbf{1}$.

All markers were in Hardy-Weinberg equilibrium. The F5 variant 1691A (FV Leiden) reached an allelic frequency of $1 \%$ in our sample; no homozygous for this variant was detected, and the heterozygous carriers (1691GA) represented $2 \%$ of the individuals analysed. Furthermore, in this locus, no homozigosity for the 4070GG polymorphism was detected. Similarly to the F5 locus, no homozigosity for the respective risk alleles was detected for F2 or APOE.

The most prevalent risk alleles observed in our sample were ACE D (61.3\%), SERPINE1 (PAI-I) 4G (45.5\%), MTHFR 1298C (32.6\%) and MTHFR 677T (31\%). Only $0.6 \%$ of the individuals had the combined $F 5$ Leiden GA-F2 GA or F5 Leiden GA-MTHFR TT genotype; $1.3 \%$ had the combined F2 GA-MTHFR TT genotype. No combined homozygous for the risk alleles at the two polymorphic positions of the MTHFR locus were observed. The frequency of combined heterozygous carriers (677CT-1298AC) in the MTHFR gene was $23 \%$. Linkage disequilibrium (LD) analysis was performed for the two polymorphic positions, at the F5 and MTHFR loci (Table 2). A strong LD between the two MTHFR polymorphism was confirmed $\left(\left|\mathrm{D}^{\prime}\right|=1 ; p<0.001\right)$ and comparison of the haplotype frequencies at this locus demonstrated that our sample was significantly different from other European, African, Chinese as well as American samples $(p<0.001)$. When comparing the allelic frequencies obtained in this study with those reported for mainland Portugal, no significant differences were observed (Figure 1). The differentiation tests also failed to disclose major differences between our sample and any of the other European samples used for comparison (data not shown).

The frequency distribution of risk alleles in our sample, and their stratification into three groups (low/moderate/high), is shown in Figure 2. All individuals carried at least four risk alleles, while the majority $(\mathrm{N}=42 / 155$; $27 \%$ ) presented with seven risk alleles. No individuals with more than eleven risk alleles were identified. The vast majority of individuals $(116 / 155 ; 75 \%)$ belong to the moderate risk group (5 - 10 risk alleles), according to our stratification. 
Table 1. Allelic and genotypic frequencies for the 12 polymorphisms analysed.

\begin{tabular}{|c|c|c|c|c|c|c|c|}
\hline Gene & SNP & Allele & $\mathbf{N}^{\mathbf{a}}$ & Freq. & Genotypes & $\mathbf{N}$ & Freq. \\
\hline F5 (FV Leiden) & $\begin{array}{c}\text { c. } 1691 \mathrm{G}>\mathrm{A}^{\mathrm{b}} \\
\left(\mathrm{rs} 6025^{\mathrm{c}}\right)\end{array}$ & $\begin{array}{l}\mathrm{G} \\
\mathrm{A}\end{array}$ & $\begin{array}{c}307 \\
3\end{array}$ & $\begin{array}{l}0.990 \\
0.010\end{array}$ & $\begin{array}{l}\text { GG } \\
\text { GA } \\
\text { AA }\end{array}$ & $\begin{array}{c}152 \\
3 \\
0\end{array}$ & $\begin{array}{l}0.980 \\
0.020 \\
0.000\end{array}$ \\
\hline F5 (R2) & $\begin{array}{l}\text { c. } 4070 A>G \\
(\text { rs } 1800595)\end{array}$ & $\begin{array}{l}\mathrm{A} \\
\mathrm{G}\end{array}$ & $\begin{array}{c}281 \\
29\end{array}$ & $\begin{array}{l}0.907 \\
0.093\end{array}$ & $\begin{array}{l}\text { AA } \\
\text { AG } \\
\text { GG }\end{array}$ & $\begin{array}{c}126 \\
29 \\
0\end{array}$ & $\begin{array}{l}0.813 \\
0.187 \\
0.000\end{array}$ \\
\hline F2 (Prothrombin) & $\begin{array}{c}\text { c. } 20210 G>A \\
(\mathrm{rs} 1799963)\end{array}$ & $\begin{array}{l}\mathrm{G} \\
\mathrm{A}\end{array}$ & $\begin{array}{c}304 \\
6\end{array}$ & $\begin{array}{l}0.981 \\
0.019\end{array}$ & $\begin{array}{l}\text { GG } \\
\text { GA } \\
\text { AA }\end{array}$ & $\begin{array}{c}149 \\
6 \\
0\end{array}$ & $\begin{array}{l}0.961 \\
0.039 \\
0.000\end{array}$ \\
\hline$F 13 A 1$ (FXIII) & $\begin{array}{l}\text { c. } 143 \mathrm{G}>\mathrm{T} \\
(\mathrm{rs} 5985)\end{array}$ & $\begin{array}{l}\mathrm{G} \\
\mathrm{T}\end{array}$ & $\begin{array}{c}237 \\
73\end{array}$ & $\begin{array}{l}0.764 \\
0.236\end{array}$ & $\begin{array}{l}\text { GG } \\
\text { GT } \\
\text { TT }\end{array}$ & $\begin{array}{c}85 \\
67 \\
3\end{array}$ & $\begin{array}{l}0.549 \\
0.432 \\
0.019\end{array}$ \\
\hline FGB (Fibrinogen) & $\begin{array}{l}\text { c. } 455 \mathrm{G}>\mathrm{A} \\
(\mathrm{rs} 1800790)\end{array}$ & $\begin{array}{l}\mathrm{G} \\
\mathrm{A}\end{array}$ & $\begin{array}{c}256 \\
54\end{array}$ & $\begin{array}{l}0.826 \\
0.174\end{array}$ & $\begin{array}{l}\text { GG } \\
\text { GA } \\
\text { AA }\end{array}$ & $\begin{array}{c}103 \\
50 \\
2\end{array}$ & $\begin{array}{l}0.665 \\
0.322 \\
0.013\end{array}$ \\
\hline SERPINE1 (PAI-I) & $\begin{array}{l}\text { c.675-676delinsG } \\
\quad(\text { rs1799889) }\end{array}$ & $\begin{array}{l}4 \mathrm{G} \\
5 \mathrm{G}\end{array}$ & $\begin{array}{l}141 \\
169\end{array}$ & $\begin{array}{l}0.455 \\
0.545\end{array}$ & $\begin{array}{l}4 \mathrm{G} / 4 \mathrm{G} \\
4 \mathrm{G} / 5 \mathrm{G} \\
5 \mathrm{G} / 5 \mathrm{G}\end{array}$ & $\begin{array}{l}37 \\
67 \\
51\end{array}$ & $\begin{array}{l}0.239 \\
0.432 \\
0.329\end{array}$ \\
\hline ITGB3 (GpIIIa) & $\begin{array}{l}\mathrm{c} .176 \mathrm{~T}>\mathrm{C} \\
(\mathrm{rs} 5918)\end{array}$ & $\begin{array}{l}1 \mathrm{a} \\
1 \mathrm{~b}\end{array}$ & $\begin{array}{c}250 \\
60\end{array}$ & $\begin{array}{l}0.806 \\
0.194\end{array}$ & $\begin{array}{l}1 \mathrm{a} 1 \mathrm{a} \\
1 \mathrm{a} 1 \mathrm{~b} \\
1 \mathrm{~b} 1 \mathrm{~b}\end{array}$ & $\begin{array}{c}103 \\
44 \\
8\end{array}$ & $\begin{array}{l}0.664 \\
0.284 \\
0.052\end{array}$ \\
\hline MTHFR & $\begin{array}{l}\text { c.677C > T } \\
(\mathrm{rs} 1801133) \\
\\
\text { c. } 1298 \mathrm{~A}>\mathrm{C} \\
(\mathrm{rs} 1801131)\end{array}$ & $\begin{array}{l}\mathrm{A} \\
\mathrm{C}\end{array}$ & $\begin{array}{c}214 \\
96 \\
\\
209 \\
101\end{array}$ & $\begin{array}{l}0.690 \\
0.310 \\
\\
0.674 \\
0.326\end{array}$ & $\begin{array}{l}\text { CC } \\
\text { CT } \\
\text { TT } \\
\text { AA } \\
\text { AC } \\
\text { CC }\end{array}$ & $\begin{array}{l}71 \\
72 \\
12 \\
68 \\
73 \\
14\end{array}$ & $\begin{array}{l}0.458 \\
0.464 \\
0.078 \\
0.439 \\
0.471 \\
0.090\end{array}$ \\
\hline$A C E$ & $\begin{array}{c}\text { g.11417_11704del287 } \\
\text { (rs } 4646994)\end{array}$ & $\begin{array}{l}\mathrm{I} \\
\mathrm{D}\end{array}$ & $\begin{array}{l}120 \\
190\end{array}$ & $\begin{array}{l}0.387 \\
0.613\end{array}$ & $\begin{array}{l}\text { II } \\
\text { ID } \\
\text { DD }\end{array}$ & $\begin{array}{l}19 \\
82 \\
54\end{array}$ & $\begin{array}{l}0.123 \\
0.529 \\
0.348\end{array}$ \\
\hline$A P O E$ & $\begin{array}{c}\text { c. } 388 \mathrm{~T}>\mathrm{C} \\
(\mathrm{rs} 429358) \\
\mathrm{c} .526 \mathrm{C}>\mathrm{T} \\
(\mathrm{rs} 7412)\end{array}$ & $\begin{array}{l}\varepsilon 2 \\
\varepsilon 3 \\
\varepsilon 4\end{array}$ & $\begin{array}{c}20 \\
253 \\
37\end{array}$ & $\begin{array}{l}0.064 \\
0.816 \\
0.120\end{array}$ & $\begin{array}{l}\varepsilon 2 / \varepsilon 2 \\
\varepsilon 2 / \varepsilon 3 \\
\varepsilon 3 / \varepsilon 3 \\
\varepsilon 2 / \varepsilon 4 \\
\varepsilon 3 / \varepsilon 4 \\
\varepsilon 4 / \varepsilon 4\end{array}$ & $\begin{array}{c}2 \\
15 \\
101 \\
1 \\
36 \\
0\end{array}$ & $\begin{array}{l}0.013 \\
0.097 \\
0.652 \\
0.006 \\
0.232 \\
0.000\end{array}$ \\
\hline
\end{tabular}

${ }^{a}$ Number of chromosomes. ${ }^{b}$ Nomenclature according to HGVS names in dbSNP (NCBI). ${ }^{c}$ dbSNP ID.

Table 2. Observed and expected frequency of the F5 and MTHFR haplotypes and |D'| value.

\begin{tabular}{|c|c|c|c|}
\hline \multicolumn{4}{|c|}{ F5 c. $1691 \mathrm{G}>\mathrm{A}$ and c. $4070 \mathrm{~A}>\mathrm{G}$ polymorphisms } \\
\hline Haplotypes & $\mathbf{N}^{\mathrm{a}}$ & Freq. $\mathbf{O b}^{\mathrm{b}}$ & Freq. Ex $^{\mathrm{c}}$ \\
\hline G-A & 278 & 0.897 & 0.897 \\
\hline G-G & 30 & 0.097 & 0.096 \\
\hline A-A & 3 & 0.006 & 0.006 \\
\hline A-G & 0 & 0.000 & 0.001 \\
\hline & & & $\left|\mathrm{D}^{\prime}\right|=0.006 ; p=0.182$ \\
\hline \multicolumn{4}{|c|}{ MTHFR c.677C $>$ T and c $1298 \mathrm{~A}>\mathrm{C}$ polymorphisms } \\
\hline Haplotypes & $\mathbf{N}^{\mathrm{a}}$ & Freq. $\mathbf{O b}^{\mathrm{b}}$ & Freq. Ex $^{\mathrm{c}}$ \\
\hline C-A & 112 & 0.361 & 0.463 \\
\hline C-C & 101 & 0.326 & 0.224 \\
\hline T-A & 97 & 0.313 & 0.211 \\
\hline \multirow[t]{2}{*}{ T-C } & 0 & 0.000 & 0.102 \\
\hline & & & $\left|\mathrm{D}^{\prime}\right|=1 ; p<0.001$ \\
\hline
\end{tabular}

${ }^{\mathrm{a}}$ number of chromosomes; ${ }^{\mathrm{b}}$ haplotype frequencies observed; ${ }^{\mathrm{c}}$ haplotype frequencies expect assuming linkage equilibrium. 

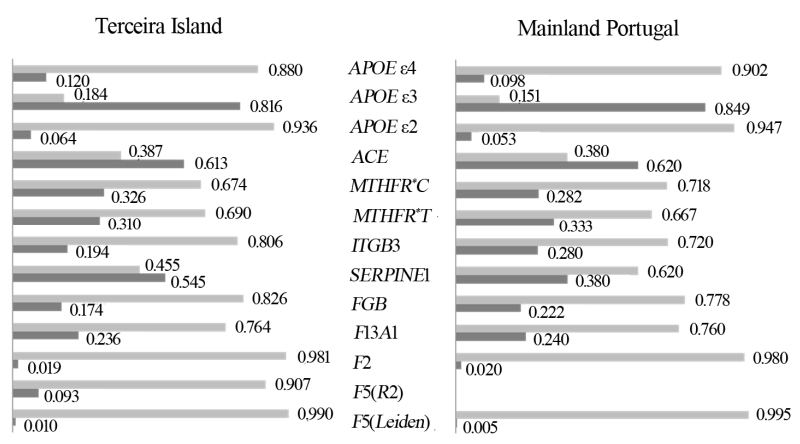

Figure 1. Allelic frequencies in the analysed population and mainland Portugal.
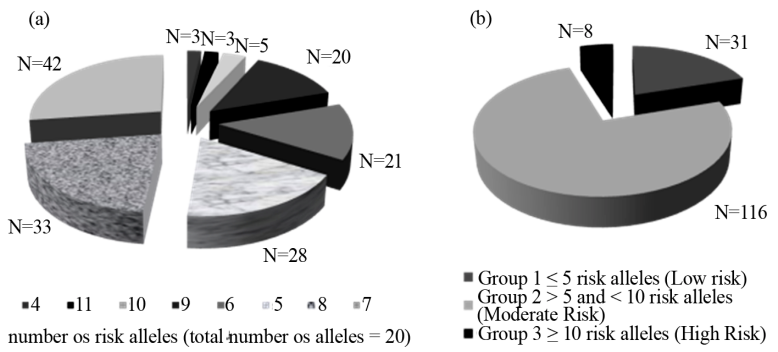

Figure 2. Prevalence of risk alleles for the 155 individuals studied; (a) and risk stratification (low/moderate/high) for the same individuals (b).

\section{DISCUSSION}

Polymorphic variation at several loci, namely at those analysed in this study, are known to modulate the risk of CVD. The knowledge of the genetic profile of any given population with respect to such loci is therefore considered important to explain its particular spectrum and prevalence of CVD manifestations.

Based on our stratification criteria, 31/155 (20\%) of Azorean subjects were found to be at low, 116/155 (75\%) at moderate and $8 / 155(5 \%)$ at high inherited number of risk alleles in susceptibility CVD loci. Although acknowledging the fact that the allelic states at these loci lack predictive value, such information can nevertheless be useful for pinpointing individuals which are at an increased risk for CVD and for whom appropriate preventive measures can be provided (e.g. anti-coagulation therapy) in known at-risk situations such as hospitalisation.

No significant differences were identified in allelic frequencies between our population and other European populations (including Mainland Portugal), which could explain the particularly high prevalence of some forms of CVD in the Azoreans. However, some loci have shown particular aspects. To the best of our knowledge, Azoreans have the lowest frequency of the FGB-455A risk variant (17.4\%) described for Europeans; its prevalence in other European countries varies from 18\% -
$22 \%$. Although the frequency of the MTHFR $677 \mathrm{~T}$ risk allele reached $31 \%$ (similarly to other European and Caucasian populations) the frequency of the homozygous TT genotype in Azores (7.8\%) was one of the lowest reported in Europe.

Synergistic effects amongst the variants encoded by the genes analyzed are known to impact in the prevalence of CVD [2]. Homozygosity or compound heterozygosity for the $F 5$ and $F 2$ risk alleles, as well as the presence of these mutations combined with the MTHFR 677TT genotype, were shown to be associated with a highly significant increase of the odds of presenting VTE [35]. In a previous study of three thrombotic risk loci in São Miguel Island (Azores), Branco and collaborators [36] found individuals with the F2 GA-MTHFR TT to represent only $0.4 \%$ of their sample while in our study this value was 3 -fold higher $(1.3 \%)$. On the other hand, only $0.6 \%$ of our subjects were F5 GA-MTHFR TT, as compared to $3.2 \%$ observed by Branco et al. [36].

Several reports have shown that the two MTHFR SNPs $(677 \mathrm{C}>\mathrm{T}$ and $1298 \mathrm{~A}>\mathrm{C})$ are in $\mathrm{LD}$ in various populations $[31,37,38]$. These SNPs were also confirmed as being in LD in our study. Resembling previous findings by van der Put et al. [39], the 677T and 1298C alleles are presented in trans configuration in our population.

The effect of genetic variants, like the ones analysed here, on the risk to develop CVD will certainly interact with other, non-genetic risk factors, such as smoking, gender, age and diet. Notwithstanding, knowledge concerning the overall profile and stratification of Azoreans for susceptibility loci should be useful, both individually and at the population level, aiming to mitigate the morbidity and mortality due to CVD.

\section{ACKNOWLEDGEMENTS}

T.C. [SFRH/BPD/38659/2007] is supported by a Post-doctoral grant from Fundação para a Ciência e a Tecnologia. N.K. [M3.1.3/F/004/ 2009] is supported by a Post-doctoral grant from the Secretaria Regional da Ciência, Tecnologia e Equipamentos.

\section{REFERENCES}

[1] Viles-Gonzalez, J.F., Fuster, V. and Badimon, J.J. (2004) Atherothrombosis: A widespread disease with unpredictable and life-threatening consequences. European Heart Journal, 25, 1197-1207. doi:10.1016/j.ehj.2004.03.011

[2] Roy, H., Bhardwaj, S. and Yla-Herttuala, S. (2009) Molecular genetics of atherosclerosis. Human Genetics, 125 467-491. doi:10.1007/s00439-009-0654-5

[3] Voetsch, B. and Loscalzo, J. (2004) Genetic determinants of arterial thrombosis. Arteriosclerosis, Thrombosis and Vascular Biology, 24, 216-229. doi:10.1161/01.ATV.0000107402.79771.fc 
[4] Elementos Estatísticos, Informação Geral Saúde (2006) "Direcção Geral de Saúde," Risco de Morrer em Portugal, 1, 85-98.

[5] Bersano, A., Ballabio, E., Bresolin, N. and Candelise, L. (2008) Genetic polymorphisms for the study of multifactorial stroke. Human Mutation, 29, 776-795. doi:10.1002/humu.20666

[6] Kottke-Marchant, K. (2002) Genetic polymorphisms associated with venous and arterial thrombosis: An overview. Archives of Pathology and Laboratory Medicine, 126, 295-304.

[7] Castoldi, E., Rosing, J., Girelli, D., Hoekema, L., et al. (2000) Mutations in the R2 FV gene affect the ratio between the two FV isoforms in plasma. Thrombosis and Haemostasis, 83, 362-365.

[8] Lane, D.A. and Grant, P.J. (2000) Role of hemostatic gene polymorphisms in venous and arterial thrombotic disease. Blood, 95, 1517-1532.

[9] Eichner, J.E., Dunn, S.T., Perveen, G., Thompson, D.M., et al. (2002) Apolipoprotein E polymorphism and cardiovascular disease: A HuGE review. American Journal of Epidemiology, 155, 487. doi:10.1093/aje/155.6.487

[10] Attié-Castro, F.A., Zago, M.A., Lavinha, J., Elion, J., et al. (2000) Ethnic heterogeneity of the factor XIII Val34Leu polymorphism. Thrombosis and Haemostasis, 84, 601-603.

[11] Castro, R. (2003) 5,10-Methylenetetrahydrofolate reducetase $677 \mathrm{C}->\mathrm{T}$ and $1298 \mathrm{~A}->\mathrm{C}$ mutations are genetic determinants of elevated homocysteine. Quarterly Journal of Medicine, 96, 297-303. doi:10.1093/qjmed/hcg039

[12] Costa, A.M., Silva, A.J., Garrido, N.D., Louro, H., et al. (2009) Association between ACE D allele and elite short distance swimming. European Journal of Applied Physiology, 106, 785-790. doi:10.1007/s00421-009-1080-z

[13] Marinho, C., Alho, I., Arduíno, D., Falcão, Luiz M., et al. (2007) GST M1/T1 and MTHFR polymorphisms as risk factors for hypertension. Biochemical and Biophysical Research Communications, 353, 344-350. doi:10.1016/j.bbrc.2006.12.019

[14] Rodrigues, M.O., Fonseca, A., Matias Dias, C., Albergaria, I., et al. (2005) APOE genotypes and dyslipidemias in a sample of the Portuguese population. Clinical Chemistry and Laboratory Medicine, 43, 907-912. doi:10.1515/CCLM.2005.155

[15] Seixas, S., Trovoada, M.J. and Rocha, J. (1999) Haplotype analysis of the apolipoprotein $\mathrm{E}$ and apolipoprotein C1 loci in Portugal and São Tomé e Príncipe (Gulf of Guinea): linkage disequilibrium evidence that APOE*4 is the ancestral APOE allele. Human Biology, 71, 10011008.

[16] Araújo, F., Santos, A., Araújo, V., Henriques, I., et al. (1999) Genetic risk factors in acute coronary disease. Haemostasis, 29, 212-218.

[17] Gialeraki, A., Politou, M., Rallidis, L., Merkouri, E., et al. (2008) Prevalence of prothrombotic polymorphisms in Greece. Genetic Testing, 12, 541-547. doi:10.1089/gte.2008.0060

[18] Hancer, V.S. and Diz-Kucukkaya, R.M. (2005) Turkish population data on the factor XIII Val34Leu, glycoprotein (GP) Ib $\alpha$ Kozak and P-selectin glycoprotein ligand 1 (PSGL-1) loci. Cell Biochemistry and Function, 23, 55-
58. doi:10.1002/cbf. 1150

[19] Wells, P.S., Anderson, J.L., Scarvelis, D.K., Doucette, S.P. and Gagnon, F. (2006) Factor XIII Val34Leu variant is protective against venous thromboembolism: A HuGE review and meta-analysis. American Journal of Epidemiology, 164, 101-109. doi:10.1093/aje/kwj179

[20] Qi, X., Ma, X., Yang, X., Fan, L., et al. (2010) Methylenetetrahydrofolate reductase polymorphisms and breast cancer risk: A meta-analysis from 41 studies with 16,480 cases and 22,388 controls. Breast Cancer Research and Treatment, 123, 499-506. doi:10.1007/s10549-010-0773-7

[21] Dong, X., Wu, J., Liang, P., Li, J., et al. (2010) Methylenetetrahydrofolate reductase C677T and A1298C polymorphisms and gastric cancer: A meta-analysis. Archives of Medical Research, 41, 125-133. doi:10.1016/j.arcmed.2010.01.001

[22] Khandanpour, N., Willis, G., Meyer, F.J., Armon, M.P., et al. (2009) Peripheral arterial disease and methylenetetrahydrofolate reductase (MTHFR) C677T mutations: A case-control study and meta-analysis. Journal of Vascular Surgery, 49, 711-718. doi:10.1016/j.jvs.2008.10.004

[23] Salem, A.H., Han, K. and Batzer, M.A. (2009) Allele frequencies of the human platelet antigen-1 in the Egyptian population. BMC Research Notes, 2, 90. doi:10.1186/1756-0500-2-90

[24] Castaman, G., Faioni, E.M., Tosetto, A. and Bernardi, F. (2003) The factor V HR2 haplotype and the risk of venous thrombosis: A meta-analysis. Haematologica, 88, 1182-1189.

[25] Bouaziz-Borgi, L., Nguyen, P., Hezard, N., Musharrafieh, U., et al. (2007) A case control study of deep venous thrombosis in relation to factor V G1691A (Leiden) and A4070G (HR2 Haplotype) polymorphisms. Experimental and Molecular Pathology, 83, 480-483. doi:10.1016/j.yexmp.2007.04.006

[26] Lucotte, G. and Mercier, G. (2001) Population genetics of factor V Leiden in Europe. Blood Cells, Molecules, and Diseases, 27, 362-367. doi:10.1006/bcmd.2001.0388

[27] Burzotta, F., Paciaroni, K., De Stefano, V., Crea, F., et al. (2004) G20210A prothrombin gene polymorphism and coronary ischaemic syndromes: A phenotype-specific metaanalysis of 12,034 subjects. Heart, 90, 82-86. doi:10.1136/heart.90.1.82

[28] Hessner, M.J., Dinauer, D.M., Luhm, R.A., Endres, J.L., et al. (1999) Contribution of the glycoprotein Ia 807TT, methylene tetrahydrofolate reductase $677 \mathrm{TT}$ and prothrombin 20210GA genotypes to prothrombotic risk among factor V 1691GA (Leiden) carriers. British Journal of Haematology, 106, 237-239. doi:10.1046/j.1365-2141.1999.01514.x

[29] Szolnoki, Z., Somogyvári, F., Kondacs, A., Szabó, M. and Fodor, L. (2002) Evaluation of the interactions of common genetic mutations in stroke subtypes. Journal of Neurology, 249, 1391-1397. doi:10.1007/s00415-002-0848-4

[30] Weiss, K.M. and Clark, A.G. (2002) Linkage disequilibrium and the mapping of complex human traits. Trends in Genetics, 18, 19-24. doi:10.1016/S0168-9525(01)02550-1

[31] Shi, M., Caprau, D., Romitti, P., Christensen, K. and Murray, J.C. (2003) Genotype frequencies and linkage 
disequilibrium in the CEPH human diversity panel for variants in folate pathway genes MTHFR, MTHFD, MTRR, RFC1, and GCP2. Birth Defects Research Part A, Clinical and Molecular Teratology, 67, 545-549. doi:10.1002/bdra.10076

[32] Excoffier, L., Laval, G. and Schneider, S. (2005) Arlequin (version 3.0): An integrated software package for population genetics data analysis. Evolutionary Bioinformatics Online, 1, 47-50.

[33] Raymont M. and Rousset F. (1995) GENEPOP (V.1.2) A population genetics software for exact tests and ecumenicism. Journal of Heredity, 95, 248-249.

[34] Inc., S. (2006) SPSS for windows: Release 15.0.0. SPSS Inc., Chicago.

[35] Almawi, W.Y., Tamim, H., Kreidy, R. and Timson, G.E. (2005) Case-control study on the contribution of factor V-Leiden, prothrombin G20210A, and MTHFR C677T mutations to the genetic susceptibility of deep venous thrombosis. Journal of Thrombosis, 19, 189-196. doi:10.1007/s11239-005-1313-x

[36] Branco, C.C., Pereirinha, T., Cabral, R., Pacheco, P.R. and Mota-Vieira, L.(2009) Thrombotic genetic risk fac- tors and warfarin pharmacogenetic variants in São Miguel's healthy population (Azores). Thrombosis Journal, 7, 9. doi:10.1186/1477-9560-7-9

[37] Freitas, A.I., Mendonça, I., Guerra, G., Brión, M., et al. (2008) Methylenetetrahydrofolate reductase gene, homocysteine and coronary artery disease: the A1298C polymorphism does matter. Inferences from a case study (Madeira, Portugal). Thrombosis Research, 122, 648-656. doi:10.1016/j.thromres.2008.02.005

[38] Hanson, N.Q., Aras, O., Yang, F. and Tsai, M.Y. (2001) C677T and A1298C polymorphisms of the methylenetetrahydrofolate reductase gene: Incidence and effect of combined genotypes on plasma fasting and post-methionine load homocysteine in vascular disease. Clinical Chemistry, 47, 661-666.

[39] Van der Put, N.., Gabreels, F., Stevens, E., Smeitink, J., et al. (1998) A second common mutation in the methylenetetrahydrofolate reductase gene: an additional risk factor for neural-tube defects? The American Journal of Human Genetics, 62, 1044-1051. doi:10.1086/301825 